\title{
PENDAPAT IMAM MAZHAB TENTANG HAK ISTRI PADA MASA IDDAH TALAK BA'IN DAN RELEVANSINYA DENGAN UNDANG-UNDANG PERKAWINAN DI INDONESIA
}

\author{
Riyan Erwin Hidayat \\ IAIN Metro
}

Email : riyanerwin@gmail.com

\begin{abstract}
Divorce is a lawful thing that Allah hates. If there is a divorce there will be a waiting period/iddah. Imam madzahib agrees that women who are divorced with divorce raj'i are entitled to a living and a place of residence during the iddah period. As for the ba'in talak, they disagree, Imam Abu Hanifah holds that the wife remains entitled to the living and living, Imam Malik and Imam Shafi'i argue that the wife is only entitled to residence alone, while Imam Ahmad ibn Hanbal argues that the wife not get a living and living rights. This opinion of Imam Ahmad, has similarities with marriage rules in Indonesia, precisely article $149 \mathrm{~b}$ Compilation of Islamic Law, which states that, husbands are obliged to give a living, maskan and kiswah to the wife who ditalak raj'i and not for the wife ditalak ba'in. This research is literature research (library research), and based on this study needs to be considered again the wife's rights in the two types of talak, so that the wife can still earn a living and a place of residence during the iddah whatever type of divorce is dropped.
\end{abstract}

Keyword: Divorce, Iddah, Imam Madzhab, KHI

\begin{abstract}
Abstrak
Perceraian merupakan perkara halal yang dibenci Allah SWT. Jika terjadi perceraian maka akan ada masa tunggu/iddah. Imam madzahib sepakat bahwa perempuan yang diceraikan dengan talak raj'i berhak mendapatkan nafkah dan tempat tinggal selama masa iddah. Sedangkan untuk talak ba' in, mereka berbeda pendapat, Imam Abu Hanifah berpendapat istri itu tetap berhak atas nafkah dan tempat tinggal, Imam Malik dan Imam Syafi'i berpendapat bahwa istri hanya berhak atas tempat tinggal saja, sedangkan Imam Ahmad ibn Hanbal berpendapat bahwa istri tidak mendapatkan hak nafkah dan tempat tinggal. Pendapat Imam Ahmad ini, memiliki persamaan dengan peraturan perkawinan di Indonesia, tepatnya pasal 149 b Kompilasi Hukum Islam, yang menyatakan bahwa, suami wajib memberikan nafkah, maskan dan kiswah kepada istri yang ditalak raj'i dan tidak untuk istri yang ditalak ba'in. Penelitian ini adalah penelitian pustaka (library research), dan berdasarkan studi ini perlu dipertimbangkan lagi hak istri pada dua jenis talak tersebut, Sehingga istri tetap bisa mendapatkan nafkah dan tempat tinggal selama masa iddah apapun jenis talak yang dijatuhkan.
\end{abstract}

Kata Kunci : Perceraian, Iddah, Imam Madzhab, KHI 


\section{PENDAHULUAN}

Setiap manusia yang lahir di dunia ini, pasti menginginkan kebahagiaan, tetapi kebahagiaan itu tidak dapat tercapai dengan mudah tanpa adanya usaha serta mematuhi semua peraturan yang ada. Salah satu proses untuk mencapai kebahagiaan adalah dengan jalan perkawinan yang berawal dari niat tulus untuk membina rumah tangga. ${ }^{1}$ Pada dasarnya tujuan perkawinan adalah untuk membentuk suatu kehidupan rumah tangga yang harmonis, sejahtera, bahagia dan kekal "Perkawinan adalah ikatan lahir batin antara seorang pria dan seorang wanita sebagai suami istri dengan tujuan membentuk keluarga yang bahagia kekal berdasarkan Ketuhanan Yang Maha Esa. ${ }^{2}$

Membina keluarga yang harmonis tidaklah mudah, di karenakan akan muncul berbagai persoalan di dalam sebuah rumah tangga yang telah dibina. Penyatuan dua manusia yang berbeda sifat dan karakter pasti akan menimbulkan masalah. Apabila masalah tersebut tidak dapat teratasi maka dapat berujung kepada perceraian. ${ }^{3}$

Perceraian merupakan sesuatu yang dibenci oleh Allah SWT, sebagaimana hadits Rasulullah SAW :

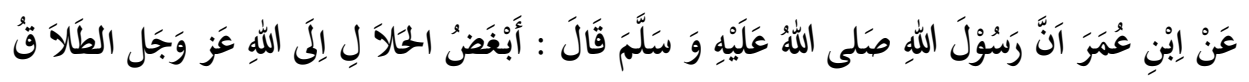

Artinya: Perbuatan halal yang dibenci Allah adalah talak. ${ }^{4}$

Melihat hadits di atas perceraian merupakan perbuatan yang halal, tetapi di benci oleh Allah SWT. ${ }^{5}$ Walaupun di benci Allah, tingkat perceraian di Indonesia dari tahun ke tahun meningkat, bahkan dari Badan Peradilan Agama (BPA) Mahkamah Agung (MA) mencatat dari tahun 2005 sampai tahun 2011 tingkat perceraian naik hingga $70 \%$ dan dalam setiap pernikahan $10 \%$ di antaranya berakhir dengan perceraian. ${ }^{6}$ Data yang terbaru tahun 2012 orang yang menikah 2.291.265 kejadian, dari jumlah tersebut mereka yang bercerai 372.577 Tahun 2013 menikah 2.218.130 kejadian, perceraian 324.572 kejadian.

Sebagai contoh di dua tahun terakhir di 2012 dan 2013 jika diambil tengahnya, angka perceraian di dua tahun itu sekitar 350.000 kasus, berarti dalam satu hari rata-rata terjadi 959 kasus perceraian, atau 40 perceraian setiap jam, apalagi sebanyak $70 \%$ perceraian terjadi karena cerai gugat dari pihak istri artinya 28 dari 40 berupa cerai gugat. ${ }^{7}$ Yang berdampak pada talak ba' in (istri tidak mendapatkan nafkah dan tempat tinggal) dimana para ulama Mazhab berbeda pendapat mengani hal ini.

\footnotetext{
${ }^{1}$ M.Anshari, Hukum Perkawinan Di indonesia, (Jakarta: Pustaka Pelajar, 2009). h 65.

${ }^{2}$ Undang-undang Pokok Perkawinan, (Jakarta: Sinar Grafika, 2000). h 2.

${ }^{3}$ Abd Rahman Ghazaly, Fiqh Munakahat, (Jakarta: Kencana, 2003). h 191

${ }^{4}$ Al Hafizh Ibn Hajar Al Asqalani, Bulughul Maram alih bahasa Machfuddin Aladip, Semarang, Toha Putra, 1985. hal 544.

${ }_{5}$ Abdul Azziz Muhammad Azzam dan Abdul Wahab Sayyeb Hawwas, Fiqh Munakahat, alih bahasa Abdul Majid Khon, Jakarta, Amzah, 2009. hal 257

${ }^{6}$ Musdalifah, "Tingkat Perceraian", dalam http://www.republika.co.id. 24 januari 2012

${ }^{7}$ http:// www.kompasiana .com/pak cah/di-indonesia-40-perceraian-setiap-jam. 8 februari 2015
} 


\section{PEMBAHASAN}

\section{Pendapat Imam Abu Hanifah Mengenai Hak Istri Pada Masa Iddah Talak Ba'in}

Abu Hanifah adalah ulama ahli ra'yu merupakan kelompok yang banyak memakai ra'yu dan jarang memakai hadis. ${ }^{8}$ Namun jika kemudian mendapatkan hadis maka mereka langsung menggunakan hadis. ${ }^{9}$ Dizaman itu ahli ra'yu meyakini keharusan memutuskan hukum berdasarkan ijtihad. Sebab kedustaan atas nama Rasulullah makin menjadi-jadi dan permasalahan juga datang silih berganti. Sehingga mazhab ini sangat mengutamakan al-Qur'an dalam mengambil hukum.

Sehingga dalam masalah fiqh mazhab hanafi juga menggunakan ra'yu dalam mengambil dalil hukum, tidak terkecuali dalam masalah perkawinan. Hal ini terlihat ketika imam Abu Hanifah mengungkapkan tentang masalah hak istri pada masa iddah talak ba'in, terutama dalam hal nafkah, yang pertama imam Abu Hanifah gunakan yaitu al-Qur'an, yaitu surat at-Thalak ayat 6 yang Artinya:

Tempatkanlah mereka (para isteri) di mana kamu bertempat tinggal menurut kemampuanmu dan janganlah kamu menyusahkan mereka untuk menyempitkan (hati) mereka. dan jika mereka (isteri-isteri yang sudah ditalaq) itu sedang hamil, Maka berikanlah kepada mereka nafkahnya hingga mereka bersalin, Kemudian jika mereka menyusukan (anak-anak)mu untukmu Maka berikanlah kepada mereka upahnya, dan musyawarahkanlah di antara kamu (segala sesuatu) dengan baik; dan jika kamu menemui kesulitan Maka perempuan lain boleh menyusukan (anak itu) untuknya.

Imam Abu Hanifah menafsirkan ayat di atas, seorang istri yang dicerai dengan talak raj'i ataupun talak ba'in dalam keadaan hamil atau tidak dia tetap berhak mendapatkan nafkah dan tempat tinggal, dari mantan suaminya selagi masa iddah berlangsung. ${ }^{10}$ Walaupun dia tidak dalam keadaan hamil, maka diwajibkan untuknya nafkah juga dalam berbagai jenis, menurut pendapat mazhab hanafi, hal ini disebabkan akibat tertahannya dia pada masa iddah demi hak suami. ${ }^{11}$

Lebih lanjut mazhab hanafi berpendapat bahwa perempuan itu berhak mendapatkan nafkah dan pakaian. ${ }^{22}$ Serta menjelaskan ayat di atas, bahwa Allah SWT, hanya mengaitkan nafkah dalam kondisi hamil adalah lebih utama, karena masa kehamilan pada umumnya adalah lama. ${ }^{13}$

\footnotetext{
${ }^{8}$ Abdul Aziz Asy-Syinawi, Biografi Imam Abu Hanifah, alih bahasa abdul Majid (Solo: Aqwam, 2012), h 74

${ }^{9}$ Abdul Aziz Asy-Syinawi, Biografi Imam Abu Hanifah, h 72

${ }^{10}$ Syams ad-Din As-Sarakhsi, al-Mabsut jilid V (Beirut: Dar al-Ma'rifah, 1989), h 201

${ }^{11}$ Wahbah Zuhaili, al-Fiqh al Islami wa Adillatuhu (Madinah: Dar Fikr Ma'asir, 2004) H 7203

${ }^{12}$ Ibnu Hajar al Asqalani, Fathul Baari, ( Jakarta: Pustaka Azzam, 2008 )., h 468

${ }^{13}$ Ibnu Hajar al Asqalani, Fathul Baari., h 469
} 
Pendapat Imam Malik bin Anas Tentang Hak Istri Pada Masa Iddah Talak Ba'in

Imam Malik menggunakan hadis sebagai dasar penetapan hukum, seperti ketika membahas hak-hak istri pada masa iddah talak ba' in, imam Malik menggunakan hadis Fatimah bin Qais yang berbunyi:

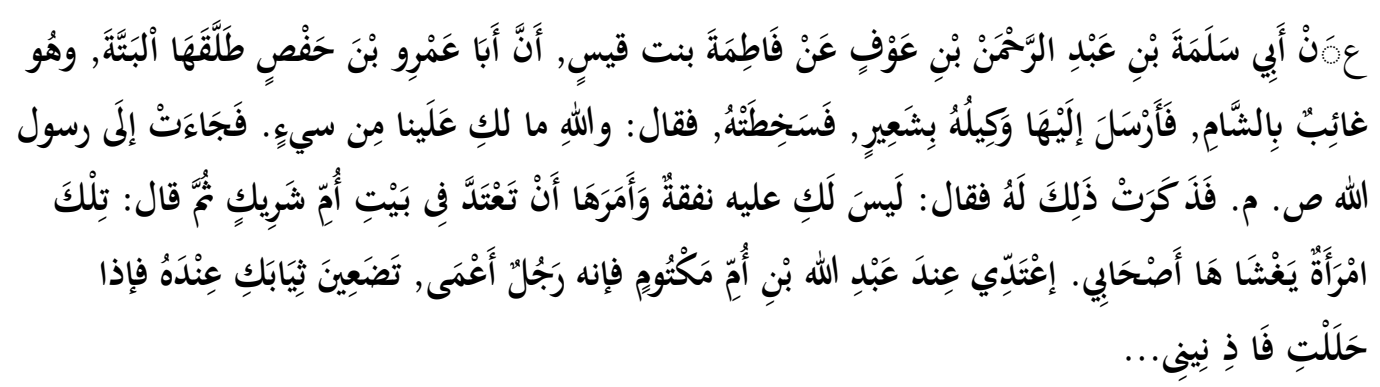

Artinya :

Dari abu Salamah bin Abdurrahman bin auf, dari Fathimah binti Qais, bahwasanya Abu Amr bin Hafsh mentalaknya ba'in, saat itu ia sedang berada di Syam, ia mengirim wakilnya untuk memberikan gandum, maka Fathimah memarahinya, lalu wakilnya itu berkata, "demi Allah, engkau tidak punya hak apa-apa terhadap kami." Maka Fathimah menemui Rasulullah SAW, lalu menceritakan hal itu kepada beliau, maka beliaupun bersabda, "ia tidak lagi berkewajiban memberi nafkah kepadamu". Lalu beliau menyuruhnya untuk menjalani masa iddahnya di rumah Ummu Syarik. Tapi kemudian beliau mengatakan, "Dia itu wanita yang sering dikunjungi oleh para sahabatku. Jalanilah masa iddahmu di tempat Abdullah bin Ummi Maktum, ia seorang laki-laki yang buta, engkau bisa menanggalkan pakaianmu di sana. Bila telah halal (telah selesai masa iddah), beritahulah Aku. (HR. Malik No. 1209). ${ }^{14}$

Hadis di atas sebenarnya, menjelaskan tentang Fatimah yang menjalani masa iddahnya dirumah Ibn Umi Maktum, dan bukan dirumah mantan suaminya yaitu, Abu Amr bin Hafsh, hal ini tentunya menunjukan bahwa Fatimah tidak mempunyai hak tempat tinggal, hal yang perlu diketahui adalah bahwa Fatimah bin Qais termasuk seorang wanita yang panjang lidahnya terhadap keluarga suaminya.15 Sehingga dalam hal ini, sahabat-sahabat lain seperti Aisyah, Marwan, Yazid ibn al-Musayyab mengingkari hadis ini, karena bisa jadi dia menyembunyikan sebab mengapa Rasulullah memerintahkannya untuk menjalani masa iddah bukan di rumah suaminya. ${ }^{16}$

Imam Malik menyatakan bahwa hak tempat tinggal diberikan kepada mantan istri, untuk semua bentuk perceraian dalam bentuk talak, raj'i ataupun ba' in baik mantan istri tersebut dalam keadaan hamil maupun tidak. ${ }^{17}$

\footnotetext{
${ }^{14}$ Malik bin Anas, Al-Muwaththa', (Jakarta: Pustaka Azzam, 2006)., h 818

${ }^{15}$ Wahyu Setiawan, Perempuan menggugat, h 47

${ }^{16}$ Wahyu Setiawan, Perempuan menggugat, h 47

${ }^{17}$ Sahnun ibn Sa'id at-Tanukhi, al-Mudawwanah al-Kubro, jilid II (Beirut: Dar al-Fikr), h 108
} 


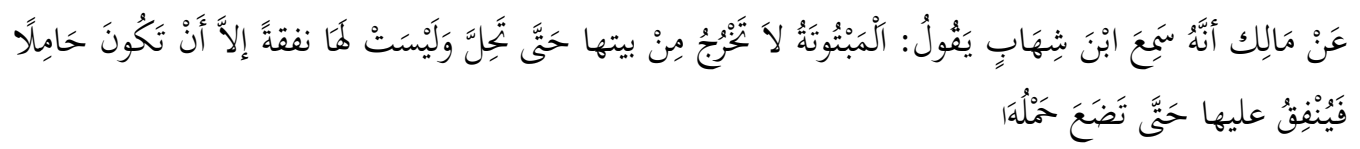

Artinya:

“Dari Malik bahwa ia mendengar Ibn Syihab berkata : wanita yang ditalak tiga tidak boleh keluar dari rumahnya hingga halal (selesai masa iddahnya), namun ia tidak mendapatkan nafkah, kecuali bila hamil ia mendapatka nafkah hingga melahirkan"

Malik mengatakan, "demikian pula pendapat kami.18" dengan demikian menurut imam Malik bahwa wanita yang dicerai dengan tala al-battah, hanya berhak menempati rumah mantan suaminya, hal ini juga didasarkan pada firman Allah, "tempatkanlah mereka (para istri) di mana kamu bertampat tinggal." (ath-Talaq: 6) di wajibkan untuk istri tempat tinggal saja apakah dia dalam keadaan hamil ataupun tidak. ${ }^{19}$

\section{Pendapat Imam Syafi'i Mengenai Hak Istri Pada Masa Iddah Talak Ba'in}

Imam Syafi' I menetapkan hak istri, ketika tertalak ba' in imam Syafi'I tidak lupa untuk menggunakan ayat al-Qur'an sebagai sumber hujah pertama, yaitu surat at-Talak ayat 6, Imam Syaf'I ketika menjelaskan ayat ini bahwa wanita, yang ditalak oleh suaminya dengan talak ba'in, bahwa dia (mantan suami) memberikan tempat tinggal secara umum kepada mantan istrinya. Dalam hal ini hanya perempuan yang hamil saja, yang berhak mendapatkan nafkah. ${ }^{20}$

Imam Syafi'I mengatakan dalil dari al-Qur'an, adalah mengenai tidak ada hak nafkah atas wanita yang suaminya tidak memiliki ruju' (ba'in). Demikian juga menurut sunnah Rasulullah SAW, imam Syafi'I juga berkata "bahwasanya Abu Amr bin Hafsh menalaknya dengan talak ba'in dimana Abu Amr berpergian ke Syam, lalu ia mengutus wakilnya kepada Fathimah dengan gandum, maka Fathimah memarahinya lalu wakilnya berkata tidak ada nafkahmu atas kami. Lalu Fathimah datang kepada Nabi SAW, lalu ia menyebutkan kepada Nabi tentang demikian maka Nabi SAW bersabda : "tidak ada nafkah bagimu atas mereka"

Lebih lanjut Abdul Majid memberitakan kepada kami dari Ibnu Juraij, ia berkata " wanita yang dithalak ba'in sedang ia dalam keadaan hamil dari padanya tidak mendapatkan sesuatu apapun kecuali laki-laki wajib memberi nafkah kepadanya karena hamil. Bila wanita itu tidak hamil maka tidak ada nafkah baginya".

Selanjutnya Imam Syafi'I mengatakan bahwa setiap wanita yang tertalak yang suaminya memiliki rujuknya maka bagi wanita itu nafkah selama wanita itu beriddah dari suami. Dan setiap wanita yang ditalak yang suaminya tidak

\footnotetext{
${ }^{18}$ Malik bin Anas, Al-Muwaththa', h 820

${ }^{19}$ Wahbah Zuhaili, al-Fiqh al Islami wa Adillatuhu (Madinah: Dar Fikr Ma'asir, 2004) H 7203

${ }^{20}$ Muhammad bin Idris Asy Safi'I, al-Umm, (Darul Hadis, 2008), h 89
} 
memiliki rujuk, maka tidak ada nafkah baginya, selama iddahnya dari laki-laki kecuali bila ia hamil, maka wajib bagi laki-laki memberikan nafkah kepadanya karena hamil. ${ }^{21}$

\section{Pendapat Imam Ahmad ibn Hanbal Mengenai Hak Istri Pada Masa Iddah Talak Ba'in}

Sehingga dalam masalah fiqh, imam ahmad terkenal dengan menggunakan hadis, terutama dalam masalah munakahat imam ahmad sering menggunakan hadis dalam ijtihadnya, salah satunya ketika membahas hak istri pada masa iddah talak ba' in, imam menggunakan hadis dari Fatimah binti Qais yang berbunyi, bahwa Rasulullah SAW bersabda,

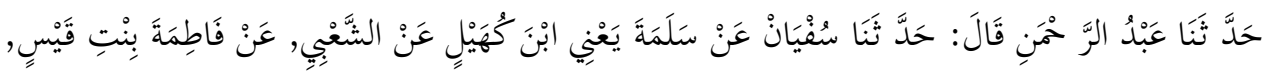



Abdurahman menceritakan kepada kami, dia berkata: Sufyan menceritakan kepada kami dari Salamah - yakni Ibnu Kuhail - dari asy-Sya'bi, dari Fatimah binti Qais, dari Nabi SAW, beliau bersabda tentang perempuan yang dithalak tiga, "dia tidak berhak mendapat tempat tinggal dan nafkah. (Musnad Imam Ahmad no: 27200) $)^{22}$

Hadis di atas ini yang digunakan oleh Ibnu Qudamah dalam kitab alMughni, bahwa apabila terjadi perpisahan karena talak tiga dan suami tidak bisa merujuk kembali, maka perempuan tersebut tidak wajib diberi tempat tinggal dan nafkah dari pihak mantan suaminya. Hal ini berlaku bila perempuan tidak hamil, sedangkan bila dia dalam keadaan hamil maka dia berhak mendapatkan nafkah karena perpisahan disaat sedang hamil. ${ }^{23}$ Hal ini tentunya di dasarkan kepada hadis Fatimah binti Qais, dimana Fatimah tidak mendapatkan nafkah dan tempat tinggal dari mantan suaminya, ketika tertalak ba'in.

\section{Hak Istri Pada Masa Iddah Menurut Perundang-Undangan Di Indonesia}

Menurut Undang-undangan No. 1 Tahun 1974, hak istri pada masa iddah dimasukan kedalam pasal 41, yaitu :

Akibat putusnya perkawinan karena perceraian adalah

a. Baik ibu atau bapak tetap berkewajiban memeliharaan mendidik anakanaknya, semata-mata berdasarkan kepentingan anak bilamana ada perselisihan mengenai penguasaan anak-anak pengadilan memberi keputusan

b. Bapak yang bertanggung jawab atas semua biaya pemeliharaan dan pendidikan yang diperlukan anak itu; bilamana bapak dalam kenyataan

\footnotetext{
${ }^{21}$ Muhammad bin Idris Asy Safi'I, al-Umm, h 89

${ }^{22}$ Imam Ahmad bin Muhammad bin Hanbal, al-Musnad, alih bahasa, Ali Murtadho dan Ibnu Arif, (Jakarta: Pustaka Azzam, 2011)., h 729

${ }^{23}$ Ibnu Qudamah, al-Mughni, (Dar kutub 2011), h 66
} 
tidak dapat memenuhi kewajiban tersebut, pengadilan dapat menentukan bahwa abu ikut memikul biaya tersebut.

c. Pengadilan dapat mewajibkan kepada bekas suami untuk memberikan biaya penghidupan dan/atau menentukan suatu kewajiban bagi bekas istri. $^{24}$

Berdasarkan pasal 41 c bahwa Pengadilan dapat mewajibkan kepada mantan suami untuk memberikan biaya penghidupan kepada mantan istrinya. Dalam Undang-undang No. 1 Tahun 1974 hanya menjelaskan sedikit saja tentang hak istri pada masa iddah, tanpa menjelaskan apakah istri yang diceraikan itu, tertalak raj'i atau ba'in, padahal apabila dilihat dari hukum Islam dampak talak raj'i dan ba'in memiliki dampak hukum yang berbeda.

Selain itu juga Penjelasan terhadap Undang-undang No.1 Tahun 1974, melalui Peraturan Pemerintah No.9 Tahun 1975 pada pasal 24 ayat 2 hanya menjelaskan :

Selama berlangsungnya gugatan perceraian atas permohonan penggugat atau tergugat, pengadilan dapat:

a. Menentukan nafkah yang harus ditanggung oleh suami

b. Menentukan hal-hal yang perlu untuk menjamin pemeliharaan dan pendidikan anak

c. Menentukan hal-hal yang perlu untuk menjamin terpeliharanya barangbarang yang menjadi hak bersama suami istri atau barang-barang yang menjadi hak istri. 25

\section{HAK ISTRI PADA MASA IDDAH TALAK BA'IN MENURUT KOMPILASI HUKUM ISLAM}

Aturan yang sedikit lebih rinci ditemukan dalam Kompilasi Hukum Islam dalam hal pemberian hak nafkah kepada istri yang tertalak, dalam ini KHI menjelaskan tentang akibat putusnya perkawinan pasal 149 yang berbunyi :

Bilamana perkawinan putus karena talak, maka bekas suami wajib :

a. Memberikan mut'ah yang layak kepada bekas istrinya, baik berupa uang atau benda, kecuali bekas istri tersebut qobla al dukhul

b. Memberi nafkah, maskan dan kiswah kepada bekas istri selama dalam iddah, kecuali bekas istri telah dijatuhi talak ba'in atau nusyuz dan dalam keadaan tidak hamil;

c. Melunasi mahar yang masih terutang seluruhnya, dan separoh apabila qobla al dukhul

d. Memberikan biaya hadhanah untuk anak-anaknya yang belum mencapai umur 21 tahun. ${ }^{26}$

Berdasarkan pasal 149 b dijelaskan bahwa mantan istri berhak mendapatkan nafkah, maskan dan kiswah selama dalam iddah talak raj'i, tetapi

\footnotetext{
${ }^{24}$ Undang-undang Nomor 1 Tahun 1974, ( bandung : Citra Umbara, 2012 ) h 14

${ }^{25}$ Undang-undang Pokok Perkawinan h 40

${ }^{26}$ Kompilasi Hukum Islam., h 149
} 
untuk iddah talak ba'in istri tidak berhak atas nafkah dan kiswah (tempat tinggal).

\section{ANALISIS PERBEDAAN MADZHAB DAN IMPLIKASINYA BAGI HUKUM DI INDONESIA}

Apabila dicermati lebih dalam tentang hak nafkah iddah talak ba'in, menurut hukum islam dalam hal ini perspektif para Imam Mazhab yang sebenarnya bersumber pada firman Allah SWT surat at-talak ayat 6 yang Artinya:

Tempatkanlah mereka (para isteri) di mana kamu bertempat tinggal menurut kemampuanmu dan janganlah kamu menyusahkan mereka untuk menyempitkan (hati) mereka. dan jika mereka (isteri-isteri yang sudah ditalaq) itu sedang hamil, Maka berikanlah kepada mereka nafkahnya hingga mereka bersalin, Kemudian jika mereka menyusukan (anak-anak)mu untukmu Maka berikanlah kepada mereka upahnya, dan musyawarahkanlah di antara kamu (segala sesuatu) dengan baik; dan jika kamu menemui kesulitan Maka perempuan lain boleh menyusukan (anak itu) untuknya.

Sehingga, imam Syafi'i menjelaskan ayat di atas bahwa wanita yang ditalak oleh suaminya, yang tidak memiliki rujuk, untuk memberikan tempat tinggal secara umum serta tidak berhak atas nafkah. Sedangkan bagi perempuan yang sedang hamil dari mereka adalah bagian yang ditunjuki oleh al-kitab bahwa tidak ada nafkah yang selain wanita hamil.27

Serta dalil yang digunakan para imam mazhab yaitu hadis dari Fatimah binti Qais yang berbunyi:

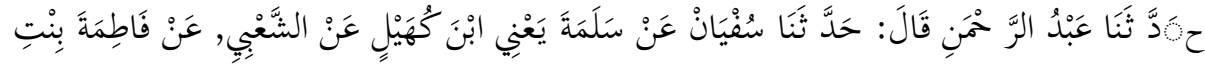

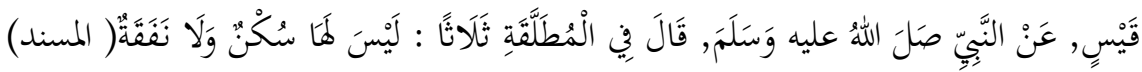

Artinya:

Abdurahman menceritakan kepada kami, dia berkata : Sufyan menceritakan kepada kami dari Salamah - yakni Ibnu Kuhail - dari asy-Sya'bi, dari Fatimah binti Qais, dari Nabi SAW, beliau bersabda tentang perempuan yang ditalak tiga, "dia tidak berhak mendapat tempat tinggal dan nafkah. (Musnad Imam Ahmad no: 27200).

Hadis di atas menurut Imam Ahmad bahwa seorang perempuan yang ditalak ba'in, oleh suaminya tidak berhak atas nafkah dan tempat tinggal. Hal ini dikarenakan talak tiga memiliki akibat suami tidak bisa merujuk kembali istrinya, oleh sebab itu istri tersebut tidak wajib diberi tempat tinggal dan nafkah.

${ }^{27}$ Muhammad bin Idris Asy Safi'I, al-Umm, (Darul Hadis, 2008), h 89 
Sebagai tambahan, bahwa sebenarnya Fatimah menjalani masa iddahnya dirumah Ibn Umi Maktum, dan bukan dirumah Abu Amr bin Hafsh yaitu mantan suaminya, hal ini menunjukan bahwa Fatimah tidak mempunyai hak tempat tinggal, perlu diketahui bahwa Fatimah bin Qais termasuk wanita yang panjang lidahnya terhadap keluarga suaminya. sehingga sahabat-sahabat lain seperti Aisyah, Marwan, Yazid ibn al-Musayyab mengingkari hadis ini, karena bisa jadi dia menyembunyikan sebab mengapa Rasulullah memerintahkannya untuk menjalani masa iddah bukan di rumah suaminya.

Walaupun sebenarnya banyak para sahabat yang menolak hadis di atas, tetapi hadis ini ditolak dikarenakan diriwayatkan oleh Fatimah binti Qais, yang terkenal dengan wanita yang panjang lidahnya, bukan karena tingkat kesahihannya, sehingga hadis ini sebenarnya dapat dijadikan hujjah oleh para ulama. Tidak hanya pendapat imam Ahmad, yang menyatakan bahwa prempuan yang ditalak ba'in tidak berhak atas nafkah dan tempat tinggal, Kompilasi Hukum Islam yang ada di Indonesia memiliki kesamaan hukum tentang hal tersebut. Hal ini dibuktikan dengan pasal $149 \mathrm{~b}$

b. Memberi nafkah, maskan dan kiswah kepada bekas istri selama dalam iddah, kecuali bekas istri telah dijatuhi talak ba'in atau nusyuz dan dalam keadaan tidak hamil;

Berdasarkan penjelasan pasal $149 \mathrm{~b}$ di atas bahwa mantan istri berhak mendapatkan nafkah, maskan dan kiswah selama dalam iddah talak raj'i, tetapi untuk iddah talak ba'in istri tidak berhak atas nafkah dan kiswah (tempat tinggal) kecuali istri tersebut dalam keadaan hamil.

Hal yang perlu dicatat adalah bahwa Kompilasi Hukum Islam itu sendiri, terbuat dari berbagai kitab fiqh yang telah dikaji dan ditelaah sebanyak 38 buah macam kitab fiqh klasik, al Mughni kitab pokok mazhab hanbali menjadi salah satunya, bilamana melihat sejarah KHi ini sendiri ternyata tidak hanya terbatas pada kitab-kitab fiqh syafi'i saja melainkan mazhab lain juga digunakan. Sehingga sangat wajar apabila suatu pendapat mazhab hanbali memiliki kesamaan dengan salah satu pasal hukum yang ada di Indonesia.

Tetapi tentunya dalam hal ini istri pihak istri akan merasa dirugikan, dikarenakan istri tidak mendapatkan nafkah dari mantan suaminya ketika menjalani masa iddah, sedangkan masa iddah yang sedang dijalani oleh istri tidak lain, dikarenakan akibat dari talak yang dijatuhkan kepadaNya. Padahal di dalam al-Qur'an sendiri pihak istri seharusnya berhak atas tempat tinggal, didasarkan pada surat at-Talak ayat 6 yang berbunyi:

Tempatkanlah mereka (para isteri) di mana kamu bertempat tinggal menurut kemampuanmu dan janganlah kamu menyusahkan mereka untuk menyempitkan (hati) mereka. dan jika mereka (isteri-isteri yang sudah ditalaq) itu sedang hamil, Maka berikanlah kepada mereka nafkahnya hingga mereka bersalin, Kemudian jika mereka menyusukan (anak-anak)mu untukmu Maka berikanlah kepada mereka upahnya, dan musyawarahkanlah di antara kamu 
(segala sesuatu) dengan baik; dan jika kamu menemui kesulitan Maka perempuan lain boleh menyusukan (anak itu) untuknya.

Berdasarkan ayat di atas, imam Syafi'i berpendapat bahwa wanita yang ditalak oleh suaminya, dengan talak ba'in, untuk memberikan tempat tinggal secara umum serta tidak berhak mendapatkan nafkah kecuali bila dia hamil.

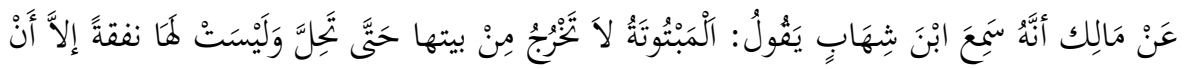

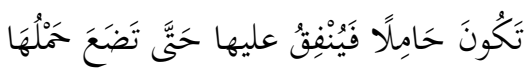

"Dari Malik bahwa ia mendengar Ibn Syihab berkata : wanita yang ditalak tiga tidak boleh keluar dari rumahnya hingga halal (selesai masa iddahnya), namun ia tidak mendapatkan nafkah, kecuali bila hamil ia mendapatka nafkah hingga melahirkan". Malik mengatakan, "demikian pula pendapat kami."28

Seperti yang sudah dijelaskan di atas bahwa, Imam Abu Hanifah memiliki pendapat yang berbeda dari imam-imam yang lain, mengenai hak isitri pada masa iddah talak ba'in ini. Dengan alasan bahwa ketika istri menjalani masa iddah, hal ini disebabkan akibat tertahannya dia pada masa iddah demi hak suami. Hal yang perlu diperhatikan dalam hal ini adalah, ketika istri menempati rumah suaminya akibat talak yang diterimanya, maka sudah barang tentu istri berhak atas nafkah dari suaminya. Mengenai hadis Fatimah binti Qais bahwa tidak mungkin untuk men-Takhsiss keumuman surah at-Talak ayat: 6 . Oleh karena itu, dalil yang paling kuat mengenai status hak nafkah, bagi perempuan yang ditalak ba' in adalah keumuman surat at-Talak ayat: 6 . Dan hal ini yang seharusnya dicontoh oleh perundang-undangan di Indonesia, bahwa istri yang tertalak raj'i atau ba'in, mendapatkan nafkah dan tempat tinggal, secara umum.

\section{KESIMPULAN}

Studi ini telah menunjukan bahwa hak nafkah perempuan pasca bercerai, sangatlah penting. Hak nafkah talak ba'in, yang diterima oleh mantan istri menurut para imam madzhab (Hanafi, Maliki, Syafi'i, Hambali) dan perundangundangan yang ada di Indonesia, memiliki perbedaan dan persamaan di antaranya yaitu :

1. Imam mazhab berbeda pendapat dalam menetapkkan hak istri pada masa iddah talak ba'in, yaitu; menurut Imam Abu Hanifah, istri yang ditalak ba' in berhak atas nafkah dan tempat tinggal. Tidak berhak atas nafkah, tetapi mendapatkan hak tempat tinggal adalah pendapat Imam Malik dan Imam Syafi'i. Tidak memberikan nafkah dan tempat tinggal adalah pendapat Imam Ahmad.

${ }^{28}$ Malik bin Anas, Al-Muwaththa', h 820 
2. Relevansi pendapat Imam Ahmad dengan perundang-undangan perkawinan di Indonesia yang terdapat dalam Kompilasi Hukum Islam pada pasal 149 b dijelaskan bahwa mantan istri berhak mendapatkan nafkah, maskan dan kiswah selama dalam iddah talak raj' $i$, tetapi untuk iddah talak ba'in istri tidak berhak atas nafkah dan kiswah (tempat tinggal).

3. Implikasi dari pasal $149 \mathrm{~b}$, istri yang ditalak ba'in tidak berhak mendapatkan nafkah dan tempat tinggal, dalam hal ini tentunya pihak istri akan merasa dirugikan, dikarenakan istri tidak mendapatkan nafkah dari mantan suaminya ketika menjalani masa iddah, sedangkan masa iddah yang sedang dijalani oleh mantan istri tidak lain, dikarenakan akibat dari talak yang dijatuhkan kepadaNya. Hal ini tentunya akan merugikan pihak istri yang selama ini hak nafkah dan tempat tinggal selalu dipenuhi oleh suaminya tersebut. Pendapat yang sebaliknya diungkapkan oleh Imam Abu Hanifah, bahwa mantan istri berhak atas nafkah dan tempat tinggal meskipun mantan istri tersebut telah dijatuhi talak ba'in oleh mantan suaminya. Hal ini tentunya akan berdampak baik bagi mantan istri tersebut, apalagi iddah yang dijalaninya untuk kebaikan keduanya (mantan suami dan mantan istri).

\section{DAFTAR PUSTAKA}

Abd Rahman Ghazaly, Fiqh Munakahat, (Jakarta: Kencana, 2003).

Abdul Aziz Asy-Syinawi, Biografi Imam Abu Hanifah, alih bahasa abdul Majid (Solo: Aqwam, 2012

Abdul Aziz Asy-Syinawi, Biografi Imam Ahmad, alih bahasa Umar Mujtahid (Solo, Aqwam, 2013)

Abdul Azziz Muhammad Azzam dan Abdul Wahab Sayyeb Hawwas, Fiqh Munakahat, alih bahasa Abdul Majid Khon, Jakarta, Amzah, 2009

Al Hafizh Ibn Hajar Al Asqalani, Bulughul Maram alih bahasa Machfuddin Aladip, Semarang, Toha Putra, 1985..

http:// www.kompasiana .com/pak cah/di-indonesia-40-perceraian-setiap-jam. 8 februari 2015

Ibnu Hajar al Asqalani, Fathul Baari, alih bahasa Amiruddin, (Jakarta: Pustaka Azzam, 2008).

Ibnu Kasir ad-Dimasyqi, Tafsir Ibnu Katsir, Alih Bahasa Bahrun Abu Bakar, (Bandung: Sinar Baru Algensindo, 2011

Ibnu Rusyd, Bidayatul Mujtahid, (Jakarta: Pustaka Amani, 2007)

Imam Ahmad bin Muhammad bin Hanbal, al-Musnad, alih bahasa, Ali Murtadho dan Ibnu Arif, (Jakarta: Pustaka Azzam, 2011).

Imam Tholkhah dan Ichtijanto, Perkawinan Perceraian, (Jakarta: Deprtemen Agama RI 2002).

Khoiruddin Nasution, Hukum Prkawinan 1, (Yogyakarta: Akademia, 2005). 
Khoiruddin Nasution, Status Wanita di Asia Tenggara, (Jakarta: Inis Leiden, 2002). Kompilasi Hukum Islam, ( Jakarta: Akademi Pressindo, 2010 ).

M.Anshari, Hukum Perkawinan Di indonesia, (Jakarta: Pustaka Pelajar, 2009). h Malik bin Anas, Al-Muwaththa', (Jakarta: Pustaka Azzam, 2006)., h 818

Muhammad ibn Idris asy Syafi'i, al Umm jilid 6, (Madinah, Darul Wafai), h., Musdalifah, "Tingkat Perceraian", dalam http://www.republika.co.id. 24 januari 2012

Sahnun ibn Sa'id at-Tanukhi, al-Mudawwanah al-Kubro, jilid II (Beirut: Dar al-Fikr) Slamet Abidin dan Aminuddin, Fiqih Munakahat, (Bandung, Pustaka Setia, 1999). Syams ad-Din As-Sarakhsi, al-Mabsut jilid V (Beirut: Dar al-Ma'rifah, 1989), Tihami dan Sohari Sahrani, Figh Munakahat I, (Jakarta: Rajawali Pers, 2009). Undang-undang Nomor 1 Tahun 1974, ( bandung : Citra Umbara, 2012 )

Undang-undang Pokok Perkawinan, (Jakarta: Sinar Grafika, 2000).

Wahbah az-Zuhaili, al-Figh al-Islami wa Adilatuhu, (Riyat: Darul Fikir Ma'asir, 2004),

Wahyu Setiawan, Hak-hak Perempuan Pasca Perceraian, Tesis tidak diterbitkan, (Yogyakarta, 2004). 